\title{
MENINGKATKAN KEMAMPUAN PEMAHAMAN KONSEP SISWA DALAM MATERI SEGITIGA MELALUI MODEL PEMBELAJARAN KOOPERATIF TIPE THINK-PAIR-SHARE (TPS) BERBANTUAN AUTOGRAPH DI KELAS VII SMP SANTO ANTONIUS JAKARTA
}

\author{
Maslina Simanjuntak \\ Dosen Program Studi Pendidikan Matematika FKIP Universitas Kristen Indonesia \\ maslin.simanjuntak@gmail.com
}

\begin{abstract}
The purpose of this research is to improve the understanding of junior high school student class VII-2 of Santo Antonius Jakarta. The method used is class activity observation using think-pair-share (TPS) learning model with the help of autograph. The result shows a classical achievement on the first cycle with $86.7 \%$ with average of 72.43 , increase of students that reach the mastery learning achievement criteria of 26 students, increase in classical achievement of $86.67 \%$, average increase of $56.6 \%$ and there's 19 students with medium increase of understanding, 11 students with high increase of understanding. Teacher's ability on executing the learning process on the first cycle is already categorized as good with 82.81, student observation result is also categorized as good eith 85.35.
\end{abstract}

Keywords: Concept Undersranding, Think Pair Share, Autograph.

\begin{abstract}
Abstrak. Tujuan penelitian ini adalah untuk meningkatkan kemampuan pemahaman konsep siswa SMP kelas VII-2 SMP Santo Antonius Jakarta. Metode yang digunakan adalah penelitian tindakan kelas (PTK) dengan menggunakan model pembelajaran thinkpair-share (TPS) berbantuan Autograph. Hasil penelitian memperlihatkan tercapai ketuntasan klasikal di siklus 1 yaitu 86,67\% dengan rata-rata 72,43, peningkatan jumlah siswa yang mencapai kriteria ketuntasan belajar sebanyak 26 orang, peningkatan ketuntasan klasikal sebesar 86,67\%, peningkatan rata-rata sebesar 56,6, dan terdapat 19 orang peningkatan kemampuan pemahaman konsep tergolong sedang, 11 peningkatannya tergolong tinggi. Kemampuan guru dalam melaksanakan kegiatan pembelajaran pada siklus I sudah termasuk kategori baik yaitu 82,81, hasil observasi siswa juga termasuk kategori baik yaitu 85,35.
\end{abstract}

Kata Kunci: Pemahaman Konsep, Think Pair Share, Autograph

\section{PENDAHULUAN}

Trends in International Mathematics and Science Study (TIMSS) merupakan ajang internasional pada bidang matematika dan sains, dimana pesertanya adalah siswa sekolah lanjutan tingkat pertama (SLTP). Ajang ini dikoordinasikan oleh IEA (The International Association for the Evaluation of Educational Achievement) yang berkedudukan di Amsterdam Belanda. TIMSS diselenggarakan setiap empat tahun sekali, yaitu pada tahun 1995, 1999, 2003, dan seterusnya. Indonesia mulai berpartisipasi sejak tahun 1999, namun keikutsertaan Indonesia dalam ajang TIMSS sejak awal pelaksanaanya tidak bedampak bagi peningkatan prestasi Indonesia khususnya pada bidang matematika. Hal ini terbukti pada tahun 2003 Indonesia masih berada pada peringkat bawah yakni peringkat ke 35 dengan skor rata-rata Indonesia untuk matematika adalah 411, dan pada tahun 2007 Indonesia berada pada peringkat ke 36 dengan skor rata-rata adalah 397 (Kemdikbud, 2011). Fakta ini jelas menunjukkan semakin menurunnya tigkat prestasi Indonesia dibidang matematika pada ajang TIMSS. 
Rendahnya prestasi Indonesia pada matematika diajang internasional disebabkan karena sebagian besar soal Trends in International Mathematics and Science Study (TIMSS) menuntut pemahaman konsep matematis, sementara faktanya kemampuan pemahaman konsep siswa Indonesia termasuk dalam kategori sangat rendah. Hal ini terbukti berdasarkan hasil tes diagnostik untuk materi segitiga yang diberikan disalah satu sekolah yang ada di Indonesia, yaitu sekolah SMP Santo Antonius Jakarta dari 30 orang siswa kelas VII-2 diperoleh rata-rata kelas 49,17 dan ketuntasan klasikal 30\%. Jawaban siswa memperlihatkan tidak tercapainya indikator dari kemampuan pemahaman konsep matematis yakni: 1) mendefinisikan konsep secara verbal dan tertulis, 2) menggunakan model, diagram, dan simbol-simbol untuk mempresentasikan suatu konsep, 3) mengidentifikasi sifat-sifat suatu konsep dan mengenal syarat yang menentukan suatu konsep, 4) membandingkan dan satu konsep dengan konsep yang lainnya. Fakta lain juga diperoleh, berdasarkan hasil observasi, dan wawancara dari hasil tes yang dilakukan oleh peneliti diperoleh informasi belum tersedianya media pembelajaran yang dapat membuat siswa merasa mudah untuk memahaminya, menemukan sendiri konsep juga menjadi penyebab rendahnya hasil tes siswa. Guru mengajar masih menggunakan pembelajaran yang bersifat teacher oriented (konvensional), dan dalam pembelajaran kemampuan awal matematis siswa juga tidak dipertimbangkan sama sekali.

Berbagai permasalahan di atas harus segera diselesaikan, para ahli pendidikan menganjurkan penggunaan model pembelajaran kooperatif (cooperative learning) untuk mengatasi masalah tersebut. Salah satu model pembelajaran kooperatif yang diharapkan dapat meningkatkan kemampuan pemahaman konsep matematis siswa adalah think-pair-share (TPS). Ada empat keunggulan pembelajaran yang menggunakan model TPS menurut Ansari (2009) yakni: (1) dapat mengembangkan pemikiran siswa dan menyatukan aspek-aspek kognitif dan aspek-aspek sosial dalam pembelajaran; (2) dapat menumbuhkan keterlibatan dan keikutsertaan siswa dengan memberikan kesempatan terbuka pada siswa untuk berbicara, mengutarakan gagasannya sendiri, dan memotivasi siswa untuk terlibat percakapan dalam kelas; (3) dapat digunakan untuk menganalisis proses berpikir siswa dan mempelajari keterampilan berkomunikasi; (4) jika digunakan secara berkelompok, diskusi dapat memadukan beberapa pendapat dan pemikiran dalam menentukan langkah-langkah penyelesaian masalah.

Model think-pair-share (TPS) merupakan salah satu model pembelajaran koooperatif yang dapat digunakan untuk meningkatkan kemampuan pemahaman konsep terbukti dari penelitian (Duha, dkk. 2012; Verowita, dkk. 2012; Zevika, dkk. 2012). Selain itu untuk mempercepat pemahaman siswa untuk konsep jenis-jenis segitiga dan pengembangannya, maka pada pelaksanaan model TPS ditambahkan media pembelajaran yaitu software Autograph.

Autograph merupakan program komputer baru yang dikembangkan oleh Douglas Butler. Ada 3 pilihan dalam penggunaannya, yaitu satu dimensi untuk statistika, dua dimensi untuk grafik, koordinat, transformasi dan geometri, dan tiga dimensi untuk grafik, koordinat, dan transformasi. Autograph memiliki tiga prinsip utama dalam penggunaanya sebagai media pembelajaran yaitu fleksibilitas, berulangulang, dan menarik simpulan (Afriati \& Saragih, 2012). Prinsip penggunaannya yang dapat digunakan secara berulang-ulang sehingga akan sangat membantu siswa mengingat, menemukan sendiri konsep matematis untuk materi segitiga. 


\section{Maslina Simanjuntak \\ Meningkatkan Kemampuan Pemahaman Konsep Siswa dalam......}

Penggunaan software Autograph di sekolah dapat meningkatkan efektivitas dan kualitas pengajaran. Hal ini senanda dengan Tarmidz (Karnasih \& Maris, 2014) yang berpendapat bahwa penggunaan Autograph membantu guru matematika untuk menyajikan materi dengan mudah, dan membuat siswa memiliki pemahaman yang lebih baik karena adanya demonstrasi visual. Senada dengan penjelasan tersebut Afriati \& Saragih (2012) menyatakan software Autograph mampu membantu siswa mencapai ketuntasan belajar, berdasarkan seluruh penjelasan di atas maka diharapkan model pembelajaran kooperatif tipe TPS berbantuan Autograph dapat meningkatkan kemampuan pemahaman konsep matematis siswa kelas VII-2 di SMP Santo Antonius Jakarta pada materi segitiga.

\section{METODE}

Jenis penelitian ini adalah penelitian tindakan kelas (Classroom Action Research). Pendekatan yang digunakan adalah pendekatan kualitatif yang berguna untuk mengungkapkan kesulitan belajar siswa dalam mempelajari materi segitiga dan pengembangannya, serta cara mengatasi kesulitan-kesulitan tersebut sebagai usaha dalam meningkatkan kemampuan pemahaman konsep matematis siswa pada materi tersebut.

\section{Siklus 1}

\section{a. Permasalahan}

Untuk mengetahui permasalahan yang ada, maka dilakukan wawancara dengan siswa, dan guru. Berdasarkan wawancara, diperoleh beberapa kesulitan yang dihadapi siswa dalam menyelesaikan soal-soal pemahaman konsep.

\section{b. Tahapan Perencanaan Tindakan I}

Tahap perencanaan tindakan I dilakukan setelah tes awal (pre test) diberikan pada siswa SMP kelas VII-2 yang akan mempelajari materi segitiga. Tes awal yang dilakukan bertujuan untuk mengetahui kemampuan awal siswa sebelum mendapatkan pembelajaran dengan model TPS berbantuan software Autograph. Pada tahap perencanaan tindakan ini, hal-hal yang dilakukan adalah:

1. Menyusun skenario pembelajaran yang berisiskan langkah-langkah kegiatan dalam pembelajaran menggunakan model pembelajaran TPS berbantuan software Autograph pada materi segitiga meliputi jenis-jenis segitiga, luas dan keliling segitiga, refleksi, dan dilatasi.

2. Mempersiapkan sarana pendukung pembelajaran yang mendukung pelaksanaan tindakan, yaitu: (a) lembar aktivitas siswa (LAS), (b) Rencana pelaksanaan pembelajaran (RPP) dengan model pembelajaran kooperatif tipe think-pair-share (TPS) berbantuan software Autograph.

3. Mempersiapkan instrumen penelitian, yaitu: 1) tes kemampuan pemahaman konsep matematis siswa; 2) lembar observasi guru (peneliti) dan siswa untuk mengamati kegiatan (proses) belajar mengajar.

\section{c. Pelaksanaan Tindakan I}

Setelah perencanaan tindakan I disusun dengan matang, maka tahap selanjutnya adalah pelaksanaan tindakan I (2xpertemuan), yaitu sebagai berikut:

\section{Pendahuluan.}

1. Membuka pembelajaran dengan mengabsen siswa.

2. Mengkondisikan siswa dan memastikan siswa siap untuk belajar.

3. Menjelaskan tentang pelaksanaan pembelajaran dengan TPS dan Autograph. 
4. Melakukan apersepsi dengan mengingatkan siswa materi yang telah dipelajari yang berhubungan dengan materi segitiga.

5. Memotivasi peserta didik agar terlibat aktif dalam pembelajaran

6. Mengemukakan tujuan pembelajaran: 1) jenis-jenis dan luas segitiga (pertemuan pertama), 2) refleksi dan dilatasi (pertemuan kedua).

7. Memasangkan siswa.

Kegiatan inti

Tahap think

1. Mengorganisasi siswa pada masalah dengan membagikan lembar aktivitas siswa (LAS) yang berisi masalah.

2. Mengumpulkan data: Meminta siswa memahami masalah 1 dan membuat penyelesaian secara individual dengan membuat catatan kecil.

\section{Tahap pair}

1. Meminta siswa untuk mendiskusikan hasil pemikirannya dengan pasangannya dengan menggunakan software Autograph, selanjutnya guru memberikan scafolding dengan membimbing siswa melakukan penyelidikan/penyelesaian dengan software Autograph dengan pasangannya dimana guru:

a. Mengarahkan siswa memahami masalah

b. Mengarahkan siswa merencanakan penyelesaian masalah

c. Mengarahkan siswa menyelesaiakan masalah sesuai dengan perencanaan

\section{Tahap share}

1. Pasangan mensharingkan hasil diskusinya dengan pasangan lain secara bebas, namun hanya boleh 2 pasangan yang bergabung (jumlah kelompok baru adalah 4 orang).

2. Meminta kelompok siswa yang telah selesai menjawab untuk menuliskan jawabannya di papan tulis dan mempresentasikannya, dan juga meminta kelompok siswa yang memiliki jawaban yang menarik untuk menuliskan jawabannya di papan tulis.

3. Meminta siswa untuk membandingkan jawaban hasil penyelidikan dari beberapa kelompok yang telah dituliskan di papan tulis melalui diskusi kelas.

4. Meminta siswa bertanya dan mengomentari penyelesaian-penyelesaian yang mereka anggap tidak benar. Memberikan kesempatan untuk menuliskan masukkannya di papan tulis.

5. Bagi kelompok siswa yang masih kurang paham dipersilahkan untuk bertanya, dan mengusahakan yang menjelaskannya adalah kelompok siswa yang sudah memahami penyelesaian masalahnya.

\section{d. Observasi I}

Pada kegiatan ini, dosen matematika UKI bertindak sebagai peneliti (guru), guru SMP Santo Antonius Jakarta, dan seorang guru matematika juga bertindak sebagai observer dengan tujuan untuk mengetahui apakah kondisi belajar mengajar sudah terlaksana sesuai dengan program pengajaran yang telah disusun oleh peneliti.

\section{e. Analisis Data I}

Data yang diperoleh dari tes kemampuan pemahaman konsep matematis siswa dianalisis, setelah itu dilakukan perhitungan untuk memperoleh hasil dari tes kemampuan pemahaman konsep untuk mengetahui apakah sudah mencapai ketentutasan klasikal.

\section{f. Refleksi I}


Dalam tahapan ini peneliti menguji apakah hasil belajar yang diperoleh dari tes kemampuan pemahaman konsep siswa sudah tuntas atau belum. Jika masih belum tuntas secara klasikal, dan kriteria hasil observasi guru dan siswa belum termasuk dalam kategori baik maka dilanjutkan siklus yang ke-II. Siklus berhenti jika tercapai ketuntasan klasikal, dan kriteria hasil observasi guru dan siswa termasuk dalam kategori baik. User (User, 2010:64) mengemukakan tentang ketuntasan belajar siswa secara individual dan klasikal yaitu:

1. Daya Serap perorangan

Seorang siswa disebut telah tuntas belajar bila ia telah mencapai skor $65 \%$ atau nilai 6,5 .

2. Daya Serap Klasikal

Suatu kelas disebut telah tuntas belajar bila di kelas tersebut telah terdapat 85 $\%$ yang telah mencapai daya serap $65 \%$.

\section{HASIL DAN PEMBAHASAN}

\section{Hasil}

Tabel 1. Tingkat Ketuntasan Tes Kemampuan Pemahaman Konsep Siswa pada Tes Diagnostik

\begin{tabular}{ccccc}
\hline $\begin{array}{c}\text { Interval } \\
\text { Penilaian }\end{array}$ & $\begin{array}{c}\text { Tingkat } \\
\text { Ketuntasan }\end{array}$ & $\begin{array}{c}\text { Banyak } \\
\text { Siswa }\end{array}$ & $\begin{array}{c}\text { Persentase } \\
\text { Jumlah Siswa }\end{array}$ & $\begin{array}{c}\text { Rata-rata } \\
\text { Nilai Siswa }\end{array}$ \\
\hline $90-100$ & Sangat Tinggi & 0 & $0 \%$ & \\
$80-89$ & Tinggi & 3 & $10 \%$ & 49,17 \\
$65-79$ & Sedang & 6 & $20 \%$ & \\
$55-64$ & Rendah & 0 & $0 \%$ & \\
$0-54$ & Sangat Rendah & 21 & $70 \%$ & \\
\hline & Jumlah & 30 & $100 \%$ & \\
\hline
\end{tabular}

Tingkat ketuntasan belajar siswa pada tes diagnostik terdapat 3 orang dari 30 siswa atau $10 \%$ yang memiliki tingkat ketuntasan tinggi, 6 orang siswa atau $20 \%$ yang memiliki tingkat ketuntasan sedang dan 21 orang siswa atau $70 \%$ yang memiliki tingkat ketuntasan sangat rendah. Skor rata-rata tes diagnostik adalah 49,17.

Tabel 2. Tingkat Ketuntasan Tes Awal (Pre Test) Kemampuan Pemahaman Konsep Siswa

\begin{tabular}{ccccc}
\hline $\begin{array}{c}\text { Interval } \\
\text { Penilaian }\end{array}$ & $\begin{array}{c}\text { Tingkat } \\
\text { Ketuntasan }\end{array}$ & $\begin{array}{c}\text { Banyak } \\
\text { Siswa }\end{array}$ & $\begin{array}{c}\text { Persentase } \\
\text { Jumlah Siswa }\end{array}$ & $\begin{array}{c}\text { Rata-rata } \\
\text { Nilai Siswa }\end{array}$ \\
\hline $90-100$ & Sangat Tinggi & 0 & $0 \%$ & \\
$80-89$ & Tinggi & 0 & $0 \%$ & 16,83 \\
$65-79$ & Sedang & 0 & $0 \%$ & \\
$55-64$ & Rendah & 0 & $0 \%$ & \\
$0-54$ & Sangat Rendah & 30 & $100 \%$ & \\
\hline \multicolumn{7}{c}{ Jumlah } & 30 & $100 \%$ &
\end{tabular}

Dari hasil tes awal kemampuan pemahaman konsep yang diberikan kepada 30 siswa, diperoleh 30 siswa tidak mencapai ketuntasan belajar (100\% siswa tidak tuntas belajar) dengan rata-rata 16,83.

Tabel 3. Deskripsi Tingkat Hasil Tes Kemampuan Pemahaman Konsep 1 


\begin{tabular}{ccccc}
\hline $\begin{array}{c}\text { Interval } \\
\text { Penilaian }\end{array}$ & $\begin{array}{c}\text { Tingkat } \\
\text { Ketuntasan }\end{array}$ & $\begin{array}{c}\text { Banyak } \\
\text { Siswa }\end{array}$ & $\begin{array}{c}\text { Persentase } \\
\text { Jumlah Siswa }\end{array}$ & Rata-rata \\
\cline { 1 - 4 } $90-100$ & $\begin{array}{c}\text { Sangat } \\
\text { Tinggi }\end{array}$ & 3 & $10,00 \%$ & \\
\cline { 1 - 4 } $80-89$ & Tinggi & 6 & $20,00 \%$ & \multirow{2}{*}{72,43} \\
\cline { 1 - 4 } $65-79$ & Sedang & 17 & $56,67 \%$ & \\
\cline { 1 - 4 } $55-64$ & Rendah & 3 & $10 \%$ & \\
\hline $0-54$ & $\begin{array}{c}\text { Sangat } \\
\text { Rendah }\end{array}$ & 1 & $3,33 \%$ & \\
\hline
\end{tabular}

Hasil tes kemampuan pemahaman konsep siklus I yang diberikan kepada 30 siswa, diperoleh 26 siswa atau 86,67\% telah mencapai tingkat ketuntasan belajar, sedangkan 4 siswa 13,33\% belum mencapai tingkat ketuntasan belajar, dengan ratarata 72,43 .

Tabel 4. Deskripsi Hasil Observasi Guru

\begin{tabular}{cccccc|}
\hline \multicolumn{6}{c|}{ Siklus 1 } \\
\cline { 1 - 4 } Observer & Pertemuan 1 & Pertemuan 2 & Rata-rata & $\begin{array}{c}\text { Rata-Rata (Obsv } \\
\text { 1+Obsv 2) }\end{array}$ & Kategori \\
\hline Observer 1 & 80 & 82,5 & 81,25 & 82,81 & Baik \\
\hline Observer 2 & 82,5 & 86,25 & 84,375 & 82 & \\
\hline
\end{tabular}

Berdasarkan tabel hasil observasi di atas, dapat dilihat bahwa kemampuan guru dalam mengajar pada pertemuan pertama, kedua, termasuk dalam kategori baik menurut kedua observer. Artinya peneliti telah mampu melaksanakan kegiatan belajar mengajar dengan model pembelajaran TPS berbantuan software Autograph dengan baik. Hasil observasi siklus I memperlihatkan bahwa peneliti telah berhasil melakukan pengelolaan waktu dengan baik, dan tekhnik bertanya peneliti juga sudah baik, sehingga siswa sudah berani untuk bertanya, aktif dalam mempresentasikan hasil diskusinya, dan memberikan tanggapan.

Tabel 5. Deskripsi Hasil Observasi Siswa

\begin{tabular}{|c|c|c|c|c|c|}
\hline \multicolumn{6}{|c|}{ Siklus 1} \\
\hline Observer & Pertemuan 1 & Pertemuan 2 & Rata-rata & $\begin{array}{c}\text { Rata-Rata (Obsv } \\
\text { 1+Obsv 2) }\end{array}$ & Kategori \\
\hline Observer 1 & 80,5 & 88,8 & 84,65 & 8535 & Roit \\
\hline Observer 2 & 83,3 & 88,8 & 86,05 & 85,35 & Balk \\
\hline
\end{tabular}

Hasil observasi siswa pada pertemuan pertama, kedua, termasuk dalam kategori baik menurut kedua observer. Hal ini terlihat dari antusias untuk bertanya, memberi tanggapan, dan merespon arahan dari guru siswa, dan siswa juga lebih berani untuk mempresentasikan hasil kerja kelompoknya untuk ditanggapi oleh kelompok lain.

\section{Pembahasan}

Model TPS berbantuan software Autograph dalam pembelajaran ini, dapat meningkatkan kemampuan pemahaman konsep matematis siswa khususnya pada materi segitiga dan pengembangannya. Hal ini didasari pada pelaksanaan tes kemampuan pemahaman konsep yang telah dilaksanakan di kelas VII-2 SMP Santo 
Antonius Jakarta. Berdasarkan hasil penelitian, dari tes diagnostik diperoleh bahwa banyak siswa yang masih rendah kemampuan pemahaman konsepnya untuk materi persegi. Dari tes diagnostik diperoleh jumlah siswa yang mencapai kategori ketuntasan tinggi 3 orang $(10 \%)$, 6 orang $(20 \%)$ ketuntasan sedang, 21 orang (70\%) ketuntasannya sangat rendah. Rata-rata untuk tes diagnostik 49,17. Ketuntasan klasikal untuk tes diagnostik $30 \%$.

Berdasarkan masalah yang ditemukan pada tes diagostik maka diperlukan perbaikan dengan melaksanakan siklus I untuk meningkatkan kemampuan pemahaman konsep matematis siswa. Namun sebelum pelaksanaan pembelajaran dengan model think pair share berbantuan software Autograph dilakukan tes awal (pre test) untuk melihat kemampuan awal pemahaman konsep siswa, untuk materi segitiga dan pengembangganya. Berdasarkan hasil tes awal (pre test), maka diperoleh jumlah siswa yang tuntas untuk materi tersebut 0 orang $(0 \%), 30$ orang siswa ketuntasan untuk tes kemampuan pemahaman konsep tergolong sangat rendah, dengan rata-rata kelas 16,83 .

Masalah tersebut diatasi dengan pemberian tindakan pada siklus I melalui pembelajaran dengan model TPS berbantuan software Autograph, diperoleh jumlah siswa yang mencapai ketuntasan belajar untuk tes kemampuan pemahaman konsep pada materi segitiga dan pengembangannya sebanyak 26 orang dari 30 orang, dan tingkat ketuntasan belajar siswa secara klasikal 86,67\% dengan rata-rata 72,43 , peningkatan jumlah siswa yang mencapai kriteria ketuntasan belajar sebanyak 26 orang dari tes awal (pre test) kemampuan pemahaman konsep matematis, peningkatan ketuntasan klasikal sebesar 86,67\%, peningkatan rata-rata sebesar 56,6, dan terdapat 19 orang peningkatan ketuntasan belajaranya untuk tes kemampuan pemahaman konsep tergolong sedang, 11 peningkatannya tergolong tinggi.

Kemampuan guru dalam melaksanakan kegiatan pembelajaran pada siklus I sudah termasuk kategori baik yaitu 82,81 , hasil observasi siswa juga termasuk kategori baik yaitu 85,35. Persentase ketuntasan belajar secara klasikal $\geq 85 \%$, dan kemampuan guru dan siswa selama pelaksanaan kegiatan pembelajaran sudah termasuk kategori baik maka tidak perlu dilaksanakan siklus II. Dari hasil penelitian ini maka dapat dikatakan bahwa model pembelajaran think pair share berbantuan Autograph dapat dijadikan sebagai alternatif untuk meningkatkan kemampuan pemahaman konsep matematis siswa khususnya pada materi segitiga dan pengembangannya.

\section{KESIMPULAN DAN SARAN Kesimpulan}

Berdasarkan hasil analisis data dan hasil observasi dapat diambil beberapa simpulan sebagai berikut:

1. Model pembelajaran think pair share berbantuan Autograph, dapat meningkatkan kemampuan pemahaman konsep matematis siswa pada materi segitiga dan pengembanggannya di kelas VII-2 SMP Santo Antonius Jakarta, dimana peningkatan diperoleh setelah siklus I dilaksanakan, dan kelas tersebut telah mencapai ketuntas belajar secara klasikal. Hal tersebut didukung oleh hasil observasi guru (kemampuan guru dalam melaksanakan pembelajaran dengan model think pair share berbantuan software Autograph termasuk kategori baik, dan siswa juga sudah aktif dalam mengikuti pembelajaran dengan model think pair share berbantuan Autograph yang dilihat dari hasil observasi siswa dalam 
mengikuti proses pembelajaran dengan model think pair share berbantuan Autograph telah mencapai kategori yang baik, sehingga tujuan pembelajaran tercapai.

2. Jawaban siswa untuk tes kemampuan pemahaman konsep dengan model pembelajaran think pair share berbantuan Autograph bervariasi khususnya untuk Saran menentukan jenis-jenis segitiga. adalah:

Berdasarkan simpulan penelitian, bahwa saran (rekomendasi) yang diajukan

1. Untuk penelitian lebih lanjut hendaknya penelitian ini dapat dilengkapi dengan meneliti aspek lain secara terperinci yang belum terjangkau dalam penelitian ini dan mendesain bahan ajar serta instrumen yang lebih lebih baik lagi.

2. Kepada peneliti lanjutan agar hasil dan perangkat penelitian ini dapat dijadikan pertimbangan untuk penelitian selanjutnya.

\section{DAFTAR PUSTAKA}

Afriari, V. dan Saragih, S. 2012. Peningkatan Pemahaman Konsep Grafik Fungsi Trigonometri Siswa SMK melalui Penemuan Terbimbing Berbantuan Software Autograph. Jurnal Pendidikan dan Kebudayaan 18 (4):368-381

Ansari, B. 2009. Komunikasi Matematika. Aceh: Yayasan Pena Banda Aceh Devisi Penerbitan.

Duha, A.K., Yerizon. Suherman. 2012. Penerapan model Think Pair Share terhadap Pemahaman Konsep. Jurnal Pendidikan Matematika FMIPA UNP 1 (1):45-50

Karnasih, I. dan Sinaga, M. 2014. Enhancing Mathematical Problem Solving and Mathematical Connection Through the Use of Dynamic Software Autograph in Cooperative Learning Think-Pair-Share (TPS). Jurnal Pendidikan Matematika 17(1):51-71

Kemdikbud. 2011. Survei Internasional TIMSS: Kemdikbud http://litbang.kemdikbud.go.id/index.php/survei-internasional-timss

User, U. 2010. Menjadi Guru Profesional. Bandung: PT Remaja Rosdakarya Offset

Verowita W, Murni D, Mirna (2012). Pengaruh Model Pembelajaran Kooperatif Tipe Think-Pair-Share Terhadap Pemahaman Konsep Dalam Pembelajaran Matematika. Jurnal Pendidikan Matematika 1(1):48-56

Zevika M., Yarman. dan Yerizon. 2012. Meningkatkan Kemampuan Pemahaman Konsep Siswa Kelas VIII SMP Negeri 2 Padang Panjang Melalaui Pembelajaran Kooperatif Tipe Think Pair Share Disertai Peta Pemikiran. Jurnal Pendidikan Matematika FMIPA UNP 1(1):45-50. 